(REVIEW ARTICLE)

\title{
Snack food consumption behavior: a systematic review of theory-based intervention strategies for changing eating behavior
}

\author{
Suwanna Mukem 1,* and Sarunya Benjakul 2 \\ ${ }^{1}$ School of Public Health, Walailak University, Nakhon Si Thammarat, Thailand. \\ ${ }^{2}$ Department of Health Education and Behavioral Sciences, Faculty of Public Health, Mahidol University, Bangkok, \\ Thailand.
}

Publication history: Received on 19 June 2020; revised on 01 July 2020; accepted on 03 July 2020

Article DOI: https://doi.org/10.30574/wjarr.2020.7.1.0216

\begin{abstract}
Health interventions have been shown to be associated with an increase in effectiveness of changing people's behaviors. However, interventions to change snack food consumption are perceived as complex intervention strategies. This systematic review aimed to identify interventions targeted at changing snack food eating behaviors and theory used in interventions. A comprehensive search strategy was performed using databases including Medline, Scopus, Web of Science, and Google Scholar. Articles published between 2010-2019, intervention studies were included and coded to determine whether and how theory was used. More than half of eligible studies on snack food consumption behavior $(56.6 \%)$ used theory in interventions. 30 articles were identified for inclusion $(\mathrm{n}=444)$. The most-often-used theories were Social Cognitive Theory, Theory of Planned Behavior/Theory of Reasoned Action, and Transtheoretical Model. Intervention strategies targeting the individual level included tailored health communication and goal setting. Commonly used strategies at the interpersonal and organizational level include social support programs and ecological models, respectively. Community-based participatory strategy was used at the community level. These strategies most construct from theories providing information that needs to be changed to promote healthy behavior. Application of theories in interventions enhanced the effectiveness to promote nutrition behavior change. Striving to use theory more thoroughly by applying and testing theories would be crucial to recommend.
\end{abstract}

Keywords: Snack food consumption; Eating behavior; Behavior change theory; Intervention; Strategy

\section{Introduction}

Snack food consumption may be one of the causes of nutritional problems worldwide among pre-school children, students, and adolescence [1]. Nutrition problems can affect appetite, leading to underweight, overweight and obesity $[2,3]$. It affects long-term health, for example, obesity is a factor of many chronic diseases such as diabetes, high blood pressure, cardiovascular disease. Diets high in calorie can contribute to increased obesity, high-sodium diets can contribute to increased blood pressure. A high-sugar diet has been linked with an increased incidence of type 2 diabetes due to the links between high sugar intake and obesity and people with diabetes are at risk for high blood pressure $[4,5]$.

There are several interventions that have been used in studies that can change people's behavior of unhealthy snack consumption by testing strategies for behavior change at individuals, interpersonal, organization and community level $[6,7,8]$. Some strategies developed theoretical foundations and combined theories or concepts that affect outcomes. Theories can be used to explain the structural and determinants of behavior and may provide a helpful basis for designing interventions to change behavior $[9,10]$.

\footnotetext{
* Corresponding author: Suwanna Mukem, Email: suwanna.mu@wu.ac.th
} 
Although large studies systematically reviewed the effectiveness of program intervention for dietary modification measures that affect health, little has been performed to review the theory-based health behavior change programs and assessed the extent to which theory is used in empirical research and the approaches.

\subsection{Purpose}

The purpose of this study was to systematically review food consumption behavior studies on strategies use and theoretical foundations, and to describe the contribution of theory-based intervention and methods in modification of snacking behaviors.

The common steps of conducting systematic review included research background, research criteria, inclusion criteria, selection procedures, checklists for process quality, procedures, data extraction strategies and methods, and synthesis of the extracted data.

There were three research questions for this review:

- What are all the relevant researches?

- Strategy interventions and foundation theories used?

- What are the key findings from intervention studies?

\section{Material and methods}

\subsection{Search strategy}

The scope of reviewed studies was 10 years published between 2010 and 2019.

2.1.1. Database: this study was conducted from 4 databases.

- Medline

- Web of Science

- Scopus

- Google Scholar

\subsubsection{Search terms}

- Medline:

- $\quad\left(\left(\right.\right.$ snack* $\left.^{*}\right)$ AND (((intervention) OR strategy) AND ((behavio* change)))

- Scopus:

- ( TITLE-ABS-KEY ( snack*) AND TITLE-ABS-KEY ( ( intervention) OR ( strategy)) AND TITLE-ABSKEY ( ( behavio* AND change ) ) AND TITLE-ABS-

- Web of Science:

- TOPIC: (snack*) AND TOPIC: ((intervention OR strategy)) AND TOPIC: (behavio* change)

- Google Scholar

- snack* AND intervention OR strategy, snack* AND behavio*

\subsection{Selection of studies}

\subsubsection{Study selection process}

Two researchers selected the relevant research that was based on the above strategy. Both researchers independently chose research studies by title and abstract, then selected from the full text. The selection process has been implemented in four steps.

- See all available research papers

- See the title of the research paper and their relevance

- See the abstracts relevant to the work, if not eliminated

- The criteria used for selection 

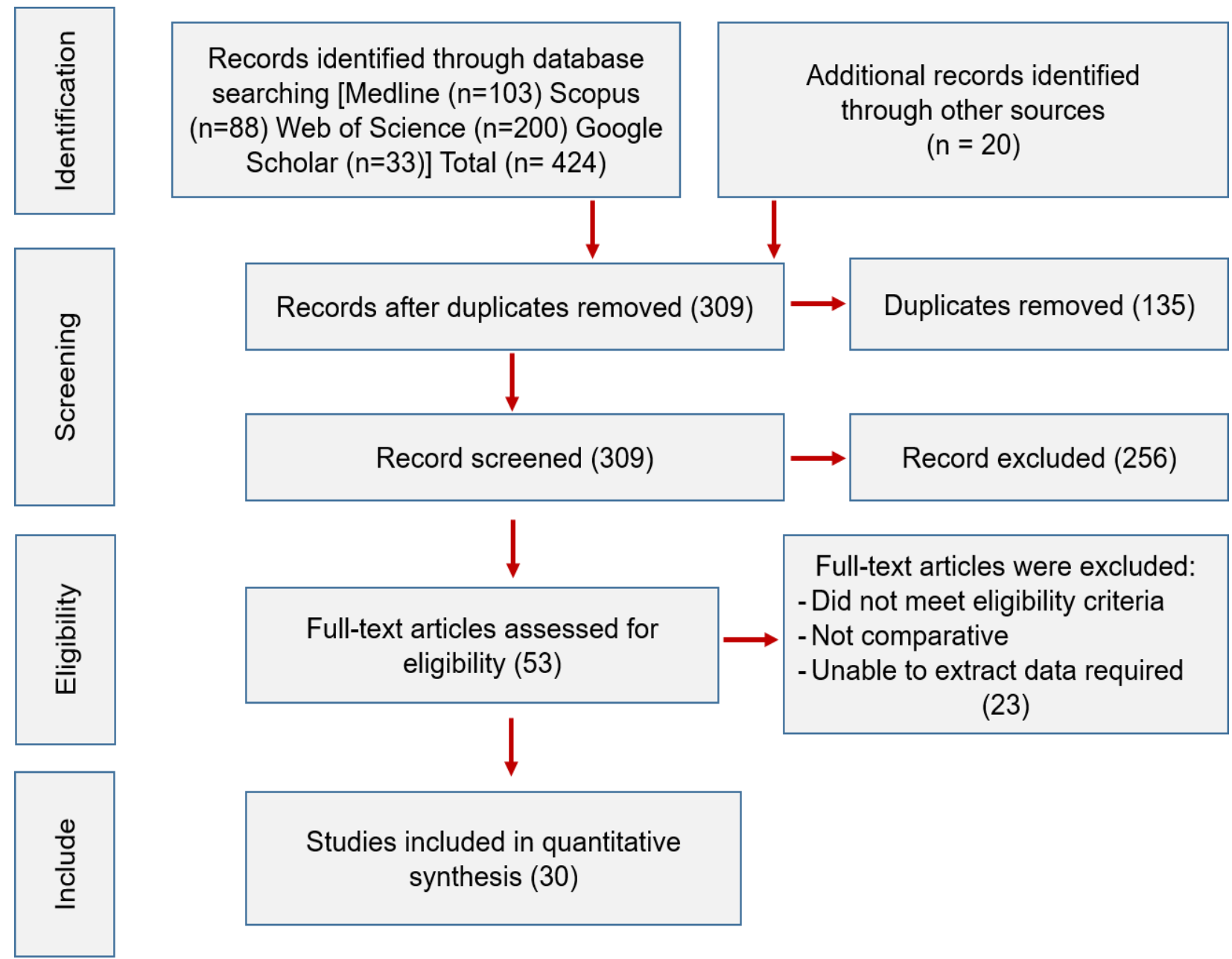

Figure 1 Flow diagram of the study search, screening and selection process

\subsubsection{Inclusion criteria}

- Had strategy/intervention for unhealthy food consumption/unhealthy eating behavior

- Applying theory/model to strategy for intervention (theory-based strategies)

- Had control/comparative group

- Had outcome measure of snacking behavior change

The search and article selection flow diagram is shown in Figure 1.

\subsection{Data extraction}

After the selection process, the researchers collected papers from a database using a program called Endnote. The collected paper from each of the selected researches, were divided into 2 parts. Part 1 extracted basic information about the research paper and Part 2 extracted the content to analyze the outcome of the measures from each paper.

\subsubsection{Baseline characteristics}

- Database name

- Number of researches collected (ID for each research paper)

- Date / month / year of search

- Journal name searched.

- Detailed information; name of the authors, publication year, objective/hypothesis 


\subsubsection{Scope of research, content and outcomes include}

- Design or research model

- Health topical focus

- Setting-based intervention

- Type of population studied, control group, number of samples

- Type of strategy and measure

- Behavioral modification theory/the basis of strategic measures used.

- Effect/Comparison results

\subsection{Quality assessment}

The quality of each study was assessed by two authors independently, using the quality assessment tool for quantitative studies developed by the Effective Public Health Practice Project (EPHPP) as a discrete step within the systematic review process [11].

\subsection{Statistical analysis}

The descriptive analyses were frequency and percentage and synthesis use qualitative approach; whether the effect of paper has the same direction or conflict, find the conclusion between the results and discuss issues of dispute.

\section{Results}

As shown in Table 1,56.6\% of eligible studies used at least one theory in interventions. Of these 30 theory-based intervention studies, the Social Cognitive Theory was mentioned in 12 articles (40.0\%). The planning models (TPB/TRA) were mentioned in 12 articles (40.0\%). The Transtheoretical Model (stages of change) was mentioned in 4 articles (13.3\%), and the other theory was mentioned 2 times (6.7\%). A same proportion of these studies examined individual and group interventions.

Table 1 Characteristics of research articles in the sample

\begin{tabular}{lll}
\hline Characteristics of articles & $\begin{array}{l}\text { Number of } \\
\text { articles (\%) }\end{array}$ & Study \\
\hline $\begin{array}{l}\text { Eligible articles (snack food consumption behavior studies) } \\
\text { Included articles (intervention including theoretical foundations) }\end{array}$ & $\begin{array}{l}\mathrm{N}=53 \\
\mathrm{n}=30 \text { (56.6\%) }\end{array}$ & [12]-[41] \\
$\begin{array}{l}\text { Study designs of included articles: } \\
\text {-Randomized controlled trial }\end{array}$ & 11 & \\
-Quasi-experimental & 19 & \\
\hline Included articles (used at least one theoretical component) & $\mathrm{n}=30$ & \\
Theory composed in the interventions of included studies: & & \\
-Social Cognitive Theory (SCT) & 12 & {$[12]-[23]$} \\
-Theory of Planned Behavior (TPB)/Theory of Reasoned Action & 12 & {$[24]-[35]$} \\
(TRA) & 4 & {$[36]-[39]$} \\
-Transtheoretical Model (TTM) & 2 & {$[40]-[41]$} \\
-others & & \\
Level of intervention in the included studies: & & \\
-Individual interventions & 15 & \\
$\quad$-Group interventions (interpersonal/organization/community) & 15 & \\
\hline
\end{tabular}

Of 30 included studies (Table 2), 12 studies (40.0\%) examined individual level of intervention, 10 studies (33.3\%) addressed organizational change, 5 studies $(16.7 \%)$ examined interpersonal change and a few addressed community interventions. Intervention strategies targeting the individual level included goal setting and tailoring. These strategies draw on Social Cognitive Theory and the stages of change construct from the Transtheoretical Model. Commonly used 
strategies at the interpersonal level include social support programs. Underlying theoretical constructs include social support and social networks. Intervention strategies at the organizational level include ecological model, provider reminders and feedback. At community level of intervention, the mentioned theory was Diffusion of Innovation Theory.

Table 2 Theory based-intervention strategies for eating behavior change in included studies

\begin{tabular}{llll}
\hline Intervention strategy & Related theories & Level of change & Study \\
\hline $\begin{array}{l}\text { Goal setting } \\
\text { Tailored communication }\end{array}$ & Social Cognitive Theory & Individual & {$[12]-[13]$} \\
Lay health advisors/ counsellors & Stages of change/Planned theory & Individual & {$[24]-[31],[36][37]$} \\
\hline $\begin{array}{l}\text { Social support programs (support } \\
\text { group/buddy) }\end{array}$ & Social support/Social network & Interpersonal & {$[14][38]$} \\
\hline $\begin{array}{l}\text { Provider reminders and feedback } \\
\text { Counsellors/consultants }\end{array}$ & Social Cognitive Theory & Interpersonal & {$[32][33][34]$} \\
& Social Cognitive Theory & Interpersonal & {$[14]$} \\
\hline Community-based participatory & Diffusion of Innovation Theory & Organization & {$[15]-[23]$} \\
\hline
\end{tabular}

Table 3 reports on theory use in sample cases and the effects of using theories for intervention design. Reviews examined which theories were used in health behavior intervention study and whether theory-based strategies are associated with outcomes.

The topical focus of reviewed papers on snack food consumption behaviors covered a range of unhealthy dietary behaviors/dietary fat habits, fruit and vegetable and exercise behaviors. These studies examined tailored print, weband mobile phone and computer-based interventions. The most-often used theories in these intervention studies were Social Cognitive Theory (SCT), Theory of Planned Behavior (TPB)/ Theory of Reasoned Action (TRA), Transtheoretical Model/stages of change (TTM). The other mentioned theoretical model that have been applied in reviewed papers were the Ecological Model, the Diffusion of Innovation Theory, Health Belief Model (HBM), and the Precaution Adoption Process Model. 
Table 3 Sample research reviews of theory used in interventions for changing snack eating behaviors

\begin{tabular}{|c|c|c|c|}
\hline Study & Setting & $\begin{array}{l}\text { Topical } \\
\text { (level of intervention) }\end{array}$ & $\begin{array}{l}\text { Theories } \\
\text { - Intervention strategy }\end{array}$ \\
\hline $\begin{array}{l}\text { SN, } 2011 \\
{[12]}\end{array}$ & USA & $\begin{array}{l}\text { Wellness Summer Camp (WSC) on } \\
\text { changes in children's knowledge } \\
\text { of healthy snack food and eating } \\
\text { behaviours, and self-perception of } \\
\text { competence in school-age } \\
\text { children (individual level) }\end{array}$ & $\begin{array}{l}\text { The programme engagement was guided } \\
\text { by SCT to help the children participate } \\
\text { activities, and camp activities were } \\
\text { developed based on age appropriate } \\
\text { developmental } \\
\text { - Support group (Trained camp } \\
\text { counselors worked with the children in } \\
\text { small groups) }\end{array}$ \\
\hline
\end{tabular}

\section{Key findings}

Children who were in the enjoyable environments guided by the theory positively perceive their self-competence and highly engage in healthy behaviours. The WSC program helps build confidence and self-competence to improve their knowledge of healthy snacks as well as motivate them to engage in healthy behaviours.

MINISTOP is based on the SCT and involves the delivery of a comprehensive, personalized program of information and Mobile-based intervention text messages based on existing DC, 2015 Sweden intended to stop obesity in preschoolers (MINISTOP) (interpersonal level) guidelines for a healthy diet and active lifestyle in pre-school children - Social support (MINSTOP app help parents promote healthy eating activity in children)

MINISTOP app has potential to be implemented in child-health care to counteract childhood obesity. Intervention content is grounded in behavior change theory (SCT) and includes evidence-based recommendations for obesity interventions targeting young children and strategies for promoting behavior change.

Using a theoretical basis was associated

Dietary fat, fruit and vegetable

$\begin{array}{lll}\text { HE, 2016 } & \text { USA } & \begin{array}{l}\text { Dietary fat, fruit and vegetable } \\ (\mathrm{F} \& \mathrm{~V})\end{array} \\ \text { [15] } & & \text { consanizational level) }\end{array}$

SCT

- Social support

constructs; (organizational level)

\section{Theory-based}

GM, 2013 USA

[23]

USA

(community level) after-school intervention
Intervention consisting with SCT, HBM and ecological model - Goal setting (incorporating hands-on activities, healthy snack preparation) with fat snack reduction and higher F\&V intake goal setting. Family and social support strategies are more effective.

Strongest interventions were enhancing.

Great Taste, Less Waste (GTLW), a TRA was used in prior successful communications campaign nutrition interventions with children capitalized on the synergy guided by the GTLW framework. between healthy eating and eco- - Additional change strategies in both friendly behaviors to motivate campaigns (GTLW and F2C) and
The GTLW and F2C campaigns were designed according to an integrated theoretical framework. GTLW was wellreceived but no significant changes were observed in the quality of food brought to 


\begin{tabular}{|c|c|c|c|c|}
\hline Study & Setting & $\begin{array}{l}\text { Topical } \\
\text { (level of intervention) }\end{array}$ & $\begin{array}{l}\text { Theories } \\
\text { - Intervention strategy }\end{array}$ & Key findings \\
\hline & & $\begin{array}{l}\text { children to bring more fruits and } \\
\text { vegetables and fewer sugar- } \\
\text { sweetened beverages (SSBs) to } \\
\text { school. } \\
\text { (individual level) }\end{array}$ & $\begin{array}{l}\text { curricula were derived from SCT, and } \\
\text { targeted knowledge, skills, and self- } \\
\text { efficacy. }\end{array}$ & $\begin{array}{l}\text { school. Whether classrooms are an } \\
\text { effective environment for change } \\
\text { remains to be explored. }\end{array}$ \\
\hline $\begin{array}{l}\text { SL, } 2015 \\
{[27]}\end{array}$ & Netherlands & $\begin{array}{l}\text { Web-based computer-tailored } \\
\text { nutrition education intervention } \\
\text { (individual level) }\end{array}$ & $\begin{array}{l}\text { TPB, self-regulation theory, and the } \\
\text { Precaution Adoption Process Model, self- } \\
\text { efficacy } \\
\text { - Goal setting, and action and coping } \\
\text { planning }\end{array}$ & $\begin{array}{l}\text { Theory were represented quite well in } \\
\text { research }\end{array}$ \\
\hline $\begin{array}{l}\text { KK, } 2014 \\
{[35]}\end{array}$ & Tanzania & $\begin{array}{l}\text { The effectiveness of a nutrition } \\
\text { education package in improving } \\
\text { feeding practices, dietary } \\
\text { adequacy and growth as } \\
\text { compared to routine health } \\
\text { education. (9 intervention and } 9 \\
\text { control villages) (community } \\
\text { level) }\end{array}$ & $\begin{array}{l}\text { TPB and Intervention Mapping provided } \\
\text { the theoretical framework for the design } \\
\text { and development of the package and the } \\
\text { intervention. } \\
\text { - The intervention trained community- } \\
\text { based peers such as village health } \\
\text { workers, lay counsellors and resource } \\
\text { persons to support mothers' behaviour } \\
\text { change. }\end{array}$ & $\begin{array}{l}\text { The intervention mapping framework } \\
\text { integrates theory, empirical findings } \\
\text { from the literature and information } \\
\text { collected from the target population to } \\
\text { develop culturally appropriate and } \\
\text { theoretically sound interventions. The } \\
\text { framework has been used successfully to } \\
\text { develop health behaviour interventions. }\end{array}$ \\
\hline $\begin{array}{l}\mathrm{AD}, 2010 \\
{[36]}\end{array}$ & USA & $\begin{array}{l}\text { Utilization of the TTM to explore } \\
\text { the readiness of the targeted } \\
\text { population to increase fruit and } \\
\text { vegetable availability to } \\
\text { preschool-aged children. } \\
\text { (individual level) }\end{array}$ & $\begin{array}{l}\text { TTM was used to determine whether } \\
\text { low-income African American parents } \\
\text { enrolled in Head Start were in } \\
\text { proportionately different stages of } \\
\text { change for increasing fruits and } \\
\text { vegetables to their young children } \\
\text { - Use of cognitive and behavioral } \\
\text { strategies related to fruit and vegetable } \\
\text { availability. }\end{array}$ & $\begin{array}{l}\text { Use of the TTM behavior change theory in } \\
\text { the study provided evidence that urban, } \\
\text { low income African-American parents of } \\
\text { children are about equally divided } \\
\text { between pre-action and } \\
\text { action/maintenance stages of change for } \\
\text { making fruits and vegetables available to } \\
\text { their children. }\end{array}$ \\
\hline $\begin{array}{l}\text { DM, } 2016 \\
{[35]}\end{array}$ & India & $\begin{array}{l}\text { A practical staging tool that could } \\
\text { be administered by community } \\
\text { volunteers to stage households in } \\
\text { rural Kerala based on readiness to } \\
\text { change dietary behaviour. } \\
\text { (community level) }\end{array}$ & $\begin{array}{l}\text { TTM was used in behaviour change } \\
\text { interventions, including } \\
\text { behaviour. } \\
\text { - Motivation Interviewing (MI), a } \\
\text { directive client-centred counselling }\end{array}$ & $\begin{array}{l}\text { TTM and Motivation Interviewing (MI) } \\
\text { integrate well together. The tool } \\
\text { represented a new concept as a staging } \\
\text { tool for households in community-based } \\
\text { dietary interventions and can be } \\
\text { administered by lay community workers. }\end{array}$ \\
\hline
\end{tabular}




\begin{tabular}{|c|c|c|c|c|c|}
\hline Study & Setting & $\begin{array}{l}\text { Topical } \\
\text { (level of intervention) }\end{array}$ & focus & $\begin{array}{l}\text { Theories } \\
\text { - Intervention strategy }\end{array}$ & Key findings \\
\hline
\end{tabular}

\begin{tabular}{|c|c|c|c|c|}
\hline $\begin{array}{l}\text { SG, } 2018 \\
{[40]}\end{array}$ & USA & $\begin{array}{l}\text { The factors (barriers and } \\
\text { enablers) that US college students } \\
\text { perceived as influencing healthy } \\
\text { eating behaviors. } \\
\text { (organizational level) }\end{array}$ & $\begin{array}{l}\text { Ecological model was used to develop a } \\
\text { framework that included individual } \\
\text { (intrapersonal), social (interpersonal), } \\
\text { university environment (community } \\
\text { settings), and students' life factors as } \\
\text { influences affecting eating habits. } \\
\text { - Consulting college students developed } \\
\text { healthy eating interventions across the } \\
\text { campus for dining services or programs. }\end{array}$ & $\begin{array}{l}\text { This model integrated individual healthy } \\
\text { and unhealthy eating patterns, in } \\
\text { combination with the main barriers and } \\
\text { enablers that are associated with health } \\
\text { decisions. Healthy eating interventions } \\
\text { across the campus such as labeling } \\
\text { healthy food options and information } \\
\text { campaigns and individual-level factors } \\
\text { and socio-ecological aspects highlighted } \\
\text { the importance. }\end{array}$ \\
\hline $\begin{array}{l}\text { BL, } 2015 \\
{[41]}\end{array}$ & USA & $\begin{array}{l}\text { Middle school-based obesity- } \\
\text { prevention intervention } \\
\text { combining } \\
\text { environmental school-wide } \\
\text { multimedia, encouragement to } \\
\text { eat healthy school cafeteria foods, } \\
\text { and peer-led education. (5 } \\
\text { intervention, 5 waitlist control) } \\
\text { (community level) }\end{array}$ & $\begin{array}{l}\text { Based on Diffusion of Innovation Theory, } \\
\text { a target group was trained as advocates } \\
\text { for optimal population diffusion of } \\
\text { information. } \\
\text { - A different group of peer leaders was } \\
\text { recruited each week; each leader was } \\
\text { asked to recruit a partner for lunchtime } \\
\text { activities. Across schools, peer leaders } \\
\text { and partners participated. }\end{array}$ & $\begin{array}{l}\text { Multilevel school-based interventions } \\
\text { may promote healthy adolescent dietary } \\
\text { behaviors. Intervention schools showed } \\
\text { significant increases in the proportion of } \\
\text { students served fruit and lunch and a } \\
\text { significant decrease in the proportion of } \\
\text { students buying snacks at school. }\end{array}$ \\
\hline \multicolumn{5}{|c|}{$\begin{array}{c}\text { SCT, social cognitive theory } \\
\text { TPB, theory of planned behavior } \\
\text { TRA, Theory of Reasoned Action } \\
\text { TTM, transtheoretical model/Stages of change } \\
\text { HBM, health belief model }\end{array}$} \\
\hline
\end{tabular}




\section{Discussion}

This review study showed that theories used to explain dietary intake related to snack food consumption were the social cognitive and the planned behavior. More than half of the studies in the reviews used theory to inform an intervention study and some of theories were applied. The findings highlight the importance of application of health behavior theories to move the field forward. Several reviews explored the use of theoretical foundation led to desirable outcomes and the effects of using theories as the basis for interventions. The use of theories that fit well with the problems and context in the studies might explain the success of theory-based interventions.

The most-often used theories in the reviewed studies were Social Cognitive Theory (SCT). Other widely mentioned theoretical models and planning frameworks were Theory of Planned Behavior (TPB) and Theory of Reasoned Action (TRA) as well as Social support and Social networks. Most of these studies examined individual and organizational interventions and few addressed interpersonal change, and community interventions. The Ecological Model and Diffusion of Innovation Theory were mentioned as theoretical model that has informed an organization and community intervention. These promising models need to be fully applied in research. The Ecological Model has been considered as an acceptable framework to link individual and social behaviors with environmental determinants, to reduce serious and prevalent health problems [42].

As a theory-based intervention, the dietary intake programme applied all of the constructs of SCT as strategies for behavioral change [43]. The Social Cognitive Theory (SCT) is a widely used theory for nutrition education programming [44]. Social cognitive theory addresses motivation and also practical behavioral capability, including skill development, self-control or volitional choice, self-direction of behavior, and impediments and facilitators of behavior change [45].

The Theory of Planned Behaviour (TPB) is an extension of the Theory of Reasoned Action (TRA). Both models are based on the premise that individuals make logical, reasoned decisions to engage in specific behaviours by evaluating the information available to them. The Theory of Reasoned Action (TRA) used in nutrition interventions guided the GTLW framework. In both GTLW and F2C, activities and messages at school were expected to influence children through changes in attitudes and perceived social norms. The Transtheoretical Model of Behavior Change (TTM) provides a framework for understanding a person's intention to make a healthful behavior change and how he or she acts upon that intention [46]. Applying Diffusion of Innovations theory in school-based intervention to promote healthy dietary behaviors spreads through a community may identify several factors that influence behavior change.

These health behavioral theories are useful to guide and develop intervention strategies. Therefore, studies based on theories are more effective in relation to behavioral changes compared to non-theoretical approaches [47]. There is evidence that theories are influenced by social and psychological determinants and that the approach is based on the self-regulation process and on how different social cognitive aspects are associated with eating behaviors [48]. Thus, application of theory should improve the effectiveness of interventions. However, most of the theories that are applied in behavior nutrition interventions provide information on what needs to be changed to promote healthy behavior but not on how change can be induced. Furthermore, some of these theories lack a strong empirical foundation and do better in explaining behavior intentions or motivation than actual behavior or behavior change.

\section{Conclusion}

Reviewed studies on snack food eating behavior have shown intervention strategies that most construct from theories. Most of the theories of behavior change applied in interventions provide information that needs to be changed to promote healthy behavior. Application of theories in interventions enhanced the effectiveness to promote nutrition behavior change. Striving to use theory more thoroughly by applying and testing theories would be crucial to recommend. Health behavior changes programs that address significant public health problems should strive to complement individually-oriented intervention models with strategies and models to develop healthier policies, systems and environments. For more effective interventions, behavior change theory needs to be further developed with stronger research designs and further development of behavior change theory should incorporate environmental change strategies. 


\section{Compliance with ethical standards}

\section{Acknowledgments}

The authors express sincere thanks to Mahidol University Library for E-database provided to access plenty of articles.

\section{Disclosure of conflict of interest}

The authors declare no conflict of interest.

\section{References}

[1] Larson NI, Miller JM, Watts A, Story M and Neumark-Sztainer N. (2016). Adolescent snacking behaviors are associated with dietary intake and weight status. The journal of nutrition, 1348-1355.

[2] Cecchini M and Sassi F. (2015). Preventing obesity in the USA: impact on health service utilization and costs. Pharmacoeconomics, 33(7), 765-776.

[3] Orsi CM, Hale D and Lynch J. (2011). Pediatric obesity epidemiology. Curr Opin Endocrinol Diabetes Obes, 18, 1422.

[4] World Health Organization. (2002). Diet, nutrition and the prevention of chronic diseases. Report of the joint WHO/FAO expert consultation. WHO Technical Report Series, No. 916 (TRS 916).

[5] Wurzbach M. (2002). Community health education and promotion: a guide to program design and evaluation. (2nded.) University of Wisconsin. Maryland: Aspen Publishers. Inc.

[6] Ashton LM, Sharkey T, Whatnall MC, Williams RL, Bezzina A and Aguiar EJ. (2019). Effectiveness of interventions and behaviour change techniques for improving dietary intake in young adults: a systematic review and metaanalysis of RCTs. Nutrients, 11, 825.

[7] Mah CL, Luongo G, Hasdell R, Taylor NGA and Lo BK. (2019) . A systematic review of the effect of retail food environment interventions on diet and health with a focus on the enabling role of public policies. Current Nutrition Reports, 8, 411-428.

[8] Schifferstein HNJ. (2020). Changing food behaviors in a desirable direction. Food Science, 33, 30-37.

[9] Kreausukon P. (2011). Health behavior change: using a theory-based nutrition intervention to improve fruit and vegetable consumption. Master's thesis, Freie Universität Berlin, Berlin, Germany.

[10] Bluethmann SM, Bartholomew K, Murphy CC and Vernon SW. (2017). Use of theory in behavior change interventions: an analysis of programs to increase physical activity in posttreatment breast cancer Survivors. Health Educ Behav, 44(2), 245-253.

[11] Effective public health practice project. (1998). Effective public health practice project (EPHPP) quality assessment tool for quantitative studies. Hamilton: Effective Public Health Practice Project.

[12] Seal N and Seal J. (2011). Developing healthy childhood behaviour: outcomes of a summer camp experience. International Journal of Nursing Practice, 17(4), 428-434.

[13] Luszczynska A, John BF de Wit, Emely de Vet, Januszewicz A, Liszewska N, Johnson F, et al. (2013). At-Home Environment, Out-of-Home Environment, Snacks and Sweetened Beverages Intake in Preadolescence, Early and Mid-Adolescence: The Interplay Between Environment and Self-Regulation. J Youth Adolescence, 42, $1873-1883$.

[14] Delisle C, Sandin S, Forsum E, Henriksson H, Trolle-Lagerros Y, Larsson C, et al. (2015). A web- and mobile phonebased intervention to prevent obesity in 4-year-olds (MINISTOP): a population-based randomized controlled trial. BMC Public Health, 15, 95.

[15] Hall E, Chai W and Albrecht JA. (2016). Relationships between nutrition-related knowledge, self-efficacy, and behavior for fifth grade students attending Title I and non-Title I schools. Appetite, 96, 245-253.

[16] Triador L, Farmer A, Maximova K, Willows N and Kootenay J. (2015). A school gardening and healthy snack program increased Aboriginal First Nations children's preferences toward vegetables and fruit. Journal of Nutrition Education and Behavior, 47(2), 176-180. 
[17] Hidayanty H, Bardosono S, Khusun H, Damayanti R and Kolopaking R. (2016). A social cognitive theory-based programme for eating patterns and sedentary activity among overweight adolescents in Makassar, South Sulawesi: a cluster randomised controlled trial. Asia Pacific Journal of Clinical Nutrition, 25(Suppl 1), S83-S92.

[18] Lloyd JJ, Logan S, Greaves CJ and Wyatt KM. (2011). Evidence, theory and context--using intervention mapping to develop a school-based intervention to prevent obesity in children. The International Journal of Behavioral Nutrition and Physical Activity, 8, 73.

[19] Majumdar D, Koch PA, Lee Gray H, Contento IR, de Lourdes Islas-Ramos A and Fu D. (2015). Nutrition Science and Behavioral Theories Integrated in a Serious Game for Adolescents. Simulation and Gaming, 46(1), 68-97.

[20] Lawlor DA, Howe LD, Anderson EL, Kipping RR, Campbell R, Wells S, et al. (2016). The Active for Life Year 5 (AFLY5) school-based cluster randomised controlled trial: effect on potential mediators. BMC Public Health, 16, 68.

[21] Majumdar D, Koch PA, Lee H, Contento IR, Islas-Ramos ADL and Fu D. (2013). "Creature-101": A Serious Game to Promote Energy Balance-Related Behaviors Among Middle School Adolescents. Games for Health Journal, 2(5), 280-290.

[22] Kipping RR, Howe LD, Jago R, et al. (2014). Effect of intervention aimed at increasing physical activity, reducing sedentary behaviour, and increasing fruit and vegetable consumption in children: active for Life Year 5 (AFLY5) school based cluster randomised controlled trial. BMJ, 348, g3256.

[23] Gutschall M and Settle J. (2013). Changes in food choices of rural preadolescent and adolescent children following a theory-based after-school nutrition intervention. Topics in Clinical Nutrition, 28(4), 356-363.

[24] Goldberg JP, Folta SC, Eliasziw M, Koch-Weser S, Economos CD, Hubbard KL, et al. (2015). Great Taste, Less Waste: A cluster-randomized trial using a communications campaign to improve the quality of foods brought from home to school by elementary school children. Preventive Medicine, 74, 103-110.

[25] Springvloet L, Lechner L, De Vries H and Oenema A. (2015). Long-term efficacy of a Web-based computer-tailored nutrition education intervention for adults including cognitive and environmental feedback: A randomized controlled trial. BMC Public Health, 15, 372.

[26] Springvloet L, Lechner L, Candel MJ, de Vries H and Oenema A. (2016). Exploring individual cognitions, selfregulation skills, and environmental-level factors as mediating variables of two versions of a Web-based computer-tailored nutrition education intervention aimed at adults: A randomized controlled trial. Appetite, 98, 101-114.

[27] Springvloet L, Lechner L, De Vries H, Candel MJJM and Oenema A. (2015). Short-and medium-term efficacy of a web-based computer-tailored nutrition education intervention for adultsincluding cognitive and environmental feedback: Randomized controlled trial. Journal of Medical Internet Research, 17(1), e23.

[28] Nazari A, Jalili Z and Tavakoli R. (2016). The Evaluation of Effects of Educational Intervention Based on Planned Behavior Theory on Reduction of Unhealthy Snack Consumption among Kermanshah Elementary School Students, 2015- 2016. International Journal of Medical Research \& Health Sciences, 5(6), 67-71.

[29] Wood C, Conner M, Sandberg T, Godin G and Sheeran P. (2014). Why does asking questions change health behaviours? The mediating role of attitude accessibility. Psychology \& Health, 29(4), 390-404.

[30] Allan JL, Sniehotta FF and Johnston M. (2013). The best laid plans: Planning skill determines the effectiveness of action plans and implementation intentions. Annals of Behavioral Medicine, 46(1), 114-120.

[31] Van Genugten L, Van Empelen P, Boon B, Borsboom G, Visscher T and Oenema A. (2012). Results from an online computer-tailored weight management intervention for overweight adults: Randomized controlled trial. Journal of Medical Internet Research, 14(2), 100-114.

[32] Ezendam NP, Brug J and Oenema A. (2012). Evaluation of the Web-based computer-tailored FATaintPHAT intervention to promote energy balance among adolescents: results from a school cluster randomized trial. Arch Pediatr Adolesc Med, 166(3), 248-255.

[33] Kocken PL, van Kesteren NMC, Buijs G, Snel J and Dusseldorp E. (2015). Students' beliefs and behaviour regarding low-calorie beverages, sweets or snacks: are they affected by lessons on healthy food and by changes to school vending machines? Public Health Nutrition, 18(9), 1545-1553.

[34] Bessems, K.M., van Assema, P., Martens, MK et al. (2012). Healthier food choices as a result of the revised healthy diet programme Krachtvoer for students of prevocational schools. Int J Behav Nutr Phys Act, 9, 60. 
[35] Kulwa KB, Verstraeten R, Bouckaert KP et al. (2014). Effectiveness of a nutrition education package in improving feeding practices, dietary adequacy and growth of infants and young children in rural Tanzania: rationale, design and methods of a cluster randomised trial. BMC Public Health, 14, 1077.

[36] Hildebrand DA and Shriver LH. (2010). A quantitative and qualitative approach to understanding fruit and vegetable availability in low-income african-american families with children enrolled in an urban head start program. Journal of the American Dietetic Association, 110(5), 710-718.

[37] Kroes L and Shahid S. (2013). Empowering young adolescents to choose the healthy lifestyle: A persuasive intervention using mobile phones. Lecture Notes in Computer Science (including subseries Lecture Notes in Artificial Intelligence and Lecture Notes in Bioinformatics). 117-126.

[38] Van Lippevelde W, van Stralen M, Verloigne M, et al. (2012). Mediating effects of home-related factors on fat intake from snacks in a school-based nutrition intervention among adolescents. Health Educ Res, 27(1), 36-45.

[39] Daivadanam M, Ravindran TKS, Thankappan KR, Sarma PS, Wahlstro"m R. (2016). Development of a Tool to Stage Households' Readiness to Change Dietary Behaviours in Kerala, India. PLoS ONE, 11(11), e0165599.

[40] Sogari G, Velez-Argumedo C, Gómez MI and Mora C. (2018). College Students and Eating Habits: A Study Using An Ecological Model for Healthy Behavior. Nutrients, 10(12), 1823.

[41] Bogart LM, Cowgill BO, Elliott MN, Klein DJ, Hawes-Dawson J, Uyeda K, Elijah J, Binkle DG and Schuster MA. (2014). A randomized controlled trial of students for nutrition and eXercise: a community-based participatory research study. The Journal of adolescent health, 55(3), 415-422.

[42] Sallis J and Owen N. (2015). Ecological models of health behavior. In Health Behaviour: Theory, Research and Practice, 5th ed.; Glanz, K., Rimer, B., Viswanath, K., Eds.; Jossey-Bass: San Francisco, CA, USA.

[43] Luszczynska A and Schwarzer R. (2005). Social cognitive theory. In: Conner M, Norman P, editors. Predicting health behaviour. London: Open University Press.

[44] Bandura A. (1986). Social foundations of thought and action: A social cognitive theory. Englewood Cliffs, NJ: Prentice-Hall.

[45] Bandura A. (2004). Health promotion by social cognitive means. Health Education \& Behavior, 31, $143-164$.

[46] Prochaska JO, Norcross JC and DiClemente CC. (1994). Changing for Good. New York, NY: HarperCollins Publishers.

[47] Cerin E, Barnett A and Baranowski T. (2009). Testing theories of dietary behavior change in youth using the mediating variable model with intervention programs. J Nutr Educ Behav, 41(5), 309-318.

[48] Plotnikoff RC, Costigan SA, Karunamuni N and Lubans DR. (2013). Social cognitive theories used to explain physical activity behavior in adolescents: a systematic review and meta-analysis. Prev Med, 56(5), 245-253.

\section{How to cite this article}

Mukem S and Benjakul S. (2020). Snack food consumption behavior: a systematic review of theory-based intervention strategies for changing eating behavior. World Journal of Advanced Research and Reviews, 12(1), 92-103. 